\title{
Computational Evaluation of ADMET Properties and Bioactive Score of Compounds from Encephalartos ferox
}

\author{
Tsolanku Sidney Maliehe ${ }^{1, *}$, Phakamani Hopewell Tsilo', Jabulani Siyabonga Shandu ${ }^{1}$
}

Tsolanku Sidney Maliehe ${ }^{1, *}$, Phakamani Hopewell Tsilo', Jabulani Siyabonga Shandu'

'Department of Biochemistry and Microbiology, Faculty of Science and Agriculture, University of Zululand, KwaDlangezwa 3886, SOUTH AFRICA.

\section{Correspondence}

\section{Tsolanku Sidney Maliehe}

Department of Biochemistry and Microbiology, Faculty of Science and Agriculture, University of Zululand, KwaDlangezwa 3886, SOUTH AFRICA.

Phone no.: +2735 9026015

E-mail: phakamanitsilo90@gmail.com History

- Submission Date: 16-04-2020;

- Review completed: 28-05-2020;

- Accepted Date: 07-06-2020

DOI : 10.5530/pj.2020.12.187

Article Available online http://www.phcogj.com/v12/i6

\section{Copyright}

(c) 2020 Phcogj.Com. This is an openaccess article distributed under the terms of the Creative Commons Attribution 4.0 International license.

\section{ABSTRACT}

Background: Plant based products are recognised as sources of drugs for treatment of diseases. Objective: The study aimed at predicting the physicochemical, pharmacokinetics, drug-likeness and toxicity of the compounds identified from the methanolic Encephalartos ferox fruit extract. Methods: The physicochemical, pharmacokinetics properties and bioactive scores of the compounds were predicted using SwissADME and Molinspiration computational tools. Drug-likeness of the compounds was evaluated based on the Lipinski rule of five (Ro5). In silico mutagenicity, carcinogenicity and inhibition of human ether-a-go-go-related (hERG) gene were also investigated using PreADMET web tool. Results: The physicochemical properties showed the compounds, except 9-Octadecenoic acid, 1, 2, 3-propanetriyl ester to adhere to Ro5. The evaluation of their inhibitory effects profile in several cytochrome P450 isoforms indicate that all the compounds are not the inhibitors of CYP2C19 and CYP3A4 whereas some inhibited CYP1A2, CYP2C9 and CYP2D6. The drug-likeness evaluation employed Ro5 as a filter and all compounds complied with it except for 9-Octadecenoic acid, 1, 2, 3-propanetriyl ester. About $50 \%$ of the tested compound were found to be safe as they did not exhibit antimutagenic and carcinogenic effects. Moreover, the risk of inhibition of hERG gene revealed to be low to medium risk depending on the compound. Conclusion: The calculated physicochemical and pharmacokinetic properties suggest that most of the compounds are safe and have promising oral bioavailability.

Key words: Compounds, Pharmacokinetic; Drug-likeness, Bioactive score, Toxicity.

\section{INTRODUCTION}

Infectious diseases continue to devastate the developing world by presenting high mortality and morbidity rates annually. ${ }^{1}$ Medicinal plants are the predominant sources of natural lead compounds used in drug discoveries and developments to combat the prevalence of infectious diseases. ${ }^{2}$ Their high potency and pharmacotherapeutic effects are owed to their diverse bioactive compounds. Among these compounds are alkaloids, saponins, tannins, glycosides and flavonoids. ${ }^{3}$ Thus, approximately $80 \%$ of the population in developing countries still rely on phytopharmaceuticals to prevent and treat different emerging and re-emerging infections. ${ }^{4}$

Many lead compounds with very interesting pharmacological properties often fail to enter the market as a result of unsatisfactory druglikeness properties and poor pharmacokinetic characteristics. ${ }^{5}$ Drugs are to be easily absorbed in the body and distributed to the targeted molecules. Moreover, they are to be easily metabolised and eliminated from blood stream without causing any toxic effects. These properties are summed up by the term ADME (absorption, distribution, metabolism and elimination) or better ADMET when toxicity studies are included. ${ }^{6}$ In addition, the lead compounds ought to possess the physicochemical properties set by different drug filters such as Lipinski's rule of five (Ro5) to be regarded as druglike compounds.
It is time consuming, tedious and costly to evaluate drug-likeness and ADMET parameters of lead compounds using conventional methods. ${ }^{8}$ Recently, computational assessments are adapted as they circumvent the high costs of unnecessary use of resources and time. ${ }^{9}$ Although computational methods are not confirmatory, they do provide information of the most likely drug-like compounds out of an array of compounds. ${ }^{10}$ Computational methods are well established in medicinal synthetic chemistry, however, their application in the field of natural compounds remain unexplored. ${ }^{11}$

Encephalartos ferox is cycad belonging to the Zamiaceae family. It is endemic in northern KwazuluNatal, South Africa. ${ }^{12}$ The plant parts, especially the leaves are used as prophylaxis in the treatment of oestrogen-dependent tumour and diabetes. ${ }^{13}$ However, there are limited studies reporting on the medicinal properties of its fruit. Our previous study investigated the chemical composition of the E. ferox methanolic fruit extract. The gas chromatography mass spectrophotometry chromatogram profile revealed a total of eight volatile compounds namely cis-Vaccenic acid (1), 9-Octadecenoic acid, 1,2,3-propanetriyl ester (2), 4H-Pyran-4-one, 2,3-dihydro-3,5-dihydroxy (3), 9-Hexadecenoic acid (4) and Pentadecanoic acid (5). Other compounds were 10-Octadecenoic acid, methyl ester (6), Hexadecanoic acid, 2-hydroxy-1-(hydroxym) (7) and 11,14-Eicosadienoic acid, methyl ester (8) These compounds have been recognised to possess

Cite this article: Maliehe TS, Tsilo PH, Shandu JS. Computational Evaluation of ADMET Properties and Bioactive Score of Compounds from Encephalartos ferox. Pharmacogn J. 2020;12(6):1357-62. 
pharmaceutical properties such as: anti-inflammatory, antimicrobial, hypolipidemic, anti-spasmodic, antioxidant, anti-proliferative, antidiabetic, anti-arthritic and anti-coronary activities. ${ }^{14-20}$ The reported pharmacological activities of these eight compounds are not solitary prerequisites for their extraction and commercialisation. To reach the market, these compounds ought to reveal satisfactory drug-likeness and pharmacokinetic properties. ${ }^{21}$

Thus, this study was designed to utilise the computational tools to predict the drug-likeness and pharmacokinetic parameters of the eight compounds previously identified from E. fruit extract. Moreover, the bioactivity was evaluated by Molinspiration computational tool.

\section{MATERIALS AND METHODS}

\section{Physicochemical, pharmacokinetics and drug-likeness properties of the compounds}

The canonical SMILES (simplified molecular input line entry system) strings of the eight identified compounds from methanolic $E$. forex fruit extract, were procured from PubChem (https//pubchem.ncbi.nlm.nih. gov/compound). They were then incorporated into SwissADME tool. The physicochemical characters of the compounds such as molecular weight (MV), number of hydrogen bond acceptors (nHBA), number of hydrogen bond donors (nHBD) and number of rotational bonds (nRB) were then predicted. The ADME parameters that include octanol-water partition coefficient lipophilicity $(\operatorname{cog} P)$, solubility, gastrointestinal absorption (GIA), blood brain barrier (BBB), p-glycoprotein (P-gp) substrate, inhibition of isoforms of cytochrome P450 (CYP), and skin permeability $(\log K p)$ were estimated by SwissADME. ${ }^{22}$ Lipinski's rule of five was applied to assess the drug-likeness of the compounds. The rule states that the drug-like compounds ought to have; $M V \leq 500$ daltons, $\mathrm{nHBA} \leq 10, \mathrm{nHBD} \leq 5$ and $\operatorname{cog} P \leq 5$. Moreover, compounds are not accepted if they show more than one violation of these set limits. ${ }^{23}$

\section{Bioactivity scores of the compounds}

The bioactivity scores of the compounds for molecules such as $G$ protein coupled receptor (GPCR) ligand, ion channel modulator, kinase inhibitor, nuclear receptor ligand and protease inhibitor were evaluated using Molinspiration Online tool (http://www.molinspiration.com). Prior to prediction of bioactivity scores, the canonical SMILES strings of the compounds from were procured from PubChem and incorporated into Molinspiration tool. ${ }^{24}$

\section{Toxicity of the compounds}

The toxicological properties of the compounds were calculated using an online server PreADMET (https://preadmet.bmdrc.kr/). The compounds were first drawn and then subjected for evaluation of toxicity by selecting ToxAlert options. Thereafter, mutagenicity and carcinogenicity profiles of the compounds were noted. ${ }^{25}$

\section{RESULTS AND DISCUSSION}

The lack of pharmacokinetic studies is one of the main hindrances in the commercialisation of the plant-based products. ${ }^{26}$ Thus, the study was designed to use computational methods to evaluate the physicochemical, pharmacokinetic and drug-likeness properties of the eight previously identified compounds from the methanolic fruit extract of Encephalartos ferox.

\section{Physicochemical properties}

All identified compounds have molecular weight in the acceptable range ( $\mathrm{MW} \leq 500)$ except for compound 2, which has the molecular weight of $885.43 \mathrm{~g} / \mathrm{mol}$. This implied that all the identified compounds with $\mathrm{MW} \leq 500$ have potential to be easily absorbed, diffused and transported when compared to compound $2 .^{27}$ Ro5 states that the drug-like compounds ought to have nHBA $\leq 10$ and $n H B D \leq 5$. The nHBA and nHBD for all tested compounds were found to be within the Lipinski's limit range (Table 1). This implies that the compounds can be well absorbed or permeable from the gastrointestinal tract when they are administrated. ${ }^{23}$ The number of rotatable bonds is a measure of molecular flexibility and is one of the widely used filter during drug discovery process. ${ }^{28}$ In this study the number of rotatable bonds of each compound was counted and the results are displayed in Table 1. The highest rotatable bonds were observed with compound $2(\mathrm{nRB}=$ $53)$ followed by $7(\mathrm{nRB}=18), 8(\mathrm{nRB}=17), 6(16), 1(\mathrm{nRB}=15), 4$ $(\mathrm{nRB}=13), 5(\mathrm{nRB}=13)$ and $3(\mathrm{nRB}=0)$. Compounds with good bioavailability have $\leq 15$ rotatable bonds. ${ }^{29}$ Compound $1,3,4$ and 5 fell within the acceptable range $(\mathrm{nRB} \leq 15)$, indicative of their potential permeability and oral bioavailability. Other tested compounds showed high number of rotatable bonds $(15 \leq \mathrm{nRB})$, hence more flexibility and poor oral bioavailability.

\section{Lipophilicity and solubility of the compounds}

Lipophilicity influences the solubility, selectivity, potency, permeability and promiscuity of lead compounds. ${ }^{30}$ The $c \operatorname{LogP}$ of the compounds are illustrated in Table 1. Compound 3, 45 and 7 adhered to the Ro5 $(\operatorname{cog} \mathrm{P} \leq 5)$, whereas compound 1, 2, 6 and 8 violated it $(\operatorname{cog} \mathrm{P}>5)$. High lipophilicity $(\operatorname{cog} \mathrm{P}>5$ ) frequently leads to compounds with high rapid metabolic turnover, low solubility and poor absorption. Moreover, an increase in lipophilicity $(\log \mathrm{P}>5)$ turns to increase the probability of compounds binding to hydrophobic protein targets other than the desired ones, consequently inducing toxic effects in biological systems. Solubility is one of the factors affecting drug absorption and distribution. ${ }^{31}$ The estimation of the aqueous solubility demonstrated that the identified compounds, except compound 2-which is insoluble, are highly to poorly soluble, depending on the LogS prediction model (Table 2). To be absorbed, compounds ought to be soluble in water so they can permeate across cell membranes. ${ }^{32}$ Thus, only compound 2 showed no probability of being absorbed and distributed.

Table 1: The physicochemical properties and lipophilicity of the identified compounds.

\begin{tabular}{|c|c|c|c|c|c|}
\hline \multirow{2}{*}{ Compounds } & \multicolumn{5}{|c|}{ Properties } \\
\hline & $\mathrm{MV}(\mathrm{g} / \mathrm{mol})$ & $\mathrm{nHBD}$ & $\mathrm{nHBA}$ & $\mathrm{nRB}$ & CLog $\mathrm{P}$ \\
\hline 1 & 282.46 & 1 & 2 & 15 & 5.68 \\
\hline 2 & 885.43 & 0 & 6 & 53 & 16.58 \\
\hline 3 & 144.13 & 2 & 4 & 0 & -0.22 \\
\hline 4 & 254.41 & 1 & 2 & 13 & 4.92 \\
\hline 5 & 242.40 & 1 & 2 & 13 & 4.84 \\
\hline 6 & 296.49 & 0 & 2 & 16 & 5.93 \\
\hline 7 & 330.50 & 2 & 4 & 18 & 4.72 \\
\hline 8 & 322.53 & 0 & 2 & 17 & 6.44 \\
\hline
\end{tabular}




\section{Pharmacokinetic properties}

The gastrointestinal absorption (GIA) of the identified compounds was predicted and the results are described in Table 4. All the compounds, except for compound 2 and 8 , revealed high probabilities of being absorbed in the gastrointestinal tract. This implies that these compounds have the potential to be absorbed in the gastrointestinal tract upon oral administration. ${ }^{33}$ The BBB is the microvascular endothelial cell layer of the brain which separates the brain from the blood. ${ }^{34}$ The compounds were evaluated for their ability to cross BBB and the results are shown in Table 4. According to the obtained results, $30 \%$ of the compounds exhibit capability to cross the $\mathrm{BBB}$. The penetration across $\mathrm{BBB}$ is only mandatory for compounds targeting the central nervous system (CNS) ${ }^{35}$ Compound 1, 2, 3, 6 and 8 did not show potential to cross BBB, hence this can be an advantage as they have less likelihood to induce adverse effects in the CNS. ${ }^{21} \mathrm{P}$-glycoproteina (P-gp) are membrane transporters of compounds in the intracellular or extracellular directions. ${ }^{36}$ Almost all compounds, except compound 2 were estimated to be non substrates for P-gp. This implies that the compounds would not be affected by the efflux action of P-gp, which turns to eliminate compounds from cells, resulting in therapeutic failure because of lower concentrations than expected. Thus, only the efficacy of compound 2 has potential to be resisted in different target sites. ${ }^{37}$

Metabolism prediction of lead compounds is one of the main priorities during drug discovery process. ${ }^{34}$ The metabolism predictions of the compounds were done against five isoforms of cytochrome $\mathrm{P} 450$ (CYP) monooxygenase family namely; CYP1A2, CYP2C19, CYP2C9, CYP2D6 and CYP3A4 and the results are displayed in Table 4. All compounds showed not to inhibit CYP2C19 and CYP3A4 whereas CYP2D6 was only inhibited by compound 7. About $50 \%$ of the compounds did not inhibit CYP2C9 while 37.5\% did not obstruct CYP1A2. Cytochrome P450 monooxygenase plays a pivotal part in drug metabolization and elimination in biological systems. The noninhibition action of the identified compounds against these enzymes implies that the compounds have high probabilities of been transformed and consequently be bioavailable upon oral administration. ${ }^{38}$ On the other hand, the inhibition of the CYP isomers by the compounds can lead to poor bioavailability as a result of failure to be metabolised and toxic side effects due to their accumulation. ${ }^{39}$ The skin is a selective barrier that allow different compounds to penetrate through at different rates depending on their physicochemical properties. ${ }^{40}$ Thus, the skin permeability $(\operatorname{LogKp})$ is a vital parameter for the assessment of compounds that might require transdermal administration. The LogKp of the compounds is presented in Table 3. All the compounds, except for compound 2 and 4 , are expected to be impermeable as they had the negative LogKp values. This implies that only compound 2 and 4 could be effectively administered through the skin. ${ }^{37}$

\section{Drug-likeness properties and bioavailability of the compounds}

Poor oral absorption of drug molecules is observed if the compounds violate more than one of Ro5. ${ }^{41}$ Ro5 was used as a filter to identify compounds that have high probability of being drug candidates and the results are shown in Table 4. All compounds, except for compound 2, can be categorised as drug-like compounds. Due to the high molecular mass and lipophilicity, compound 2 failed to comply Lipinski rules of five.

Bioavailability defines the extent and rate at which compounds administered enter systemic circulation and ultimately reach the targeted sites upon oral administration. ${ }^{42}$ The oral bioavailability results of the compounds are shown in Table 4. Most of the compounds have the bioavailable value of 0.55 and 0.56 . The 0.55 and 0.56 values imply that the compounds adhere to Lipinski rule of five and have 55 and $56 \%$ probabilities of being bioavailable..$^{23}$ Only compound 2 was classified as having low probability of attaining the bioavailability endpoints $(\geq 0.5)$. Nevertheless, if compound 2 is to be used for drug discovery due to its therapeutic benefits, it ought to be modified to improve its bioavailability.

\section{Bioactivity score}

The computed bioactivity scores of the compounds are displayed in Table 5 . The bioactivity scores for compounds are interpreted as active (scores $>0$ ), moderately active (scores: -5.0-0.0) and inactive (bioactivity score $<-5.0) .^{43}$ Among the tested compounds, compound $1,6,7$, and 8 were found to be active $G$ protein coupled receptor ligands $(\leq 0)$ while compounds 2, 3, 4 and 5 are moderate ligands. Compound 1 and 8 exhibited active activities as ion channel modulators $(0.07$

Table 2: Solubility predictions of the identified compounds.

\begin{tabular}{|c|c|c|c|c|c|c|c|c|}
\hline \multirow{2}{*}{ Properties } & \multicolumn{8}{|c|}{ Compounds } \\
\hline & 1 & 2 & 3 & 4 & 5 & 6 & 7 & 8 \\
\hline $\begin{array}{c}\text { LogS (ESOL) } \\
\text { Class }\end{array}$ & $\begin{array}{c}-5.41 \\
\text { Moderately } \\
\text { soluble }\end{array}$ & $\begin{array}{c}-15.94 \\
\text { Insoluble }\end{array}$ & $\begin{array}{l}-0.50 \\
\text { Very soluble }\end{array}$ & $\begin{array}{c}-4.70 \\
\text { Moderately } \\
\text { soluble }\end{array}$ & $\begin{array}{c}-4.66 \\
\text { Moderately } \\
\text { soluble }\end{array}$ & $\begin{array}{c}-5.32 \\
\text { Moderately } \\
\text { soluble }\end{array}$ & $\begin{array}{c}-5.69 \\
\text { Moderately } \\
\text { soluble }\end{array}$ & $\begin{array}{c}-4.57 \\
\text { Moderately } \\
\text { soluble }\end{array}$ \\
\hline $\begin{array}{l}\text { LogS }(\text { Ali }) \\
\text { Class }\end{array}$ & $\begin{array}{c}-8.26 \\
\text { Poorly soluble }\end{array}$ & $\begin{array}{c}-24.44 \\
\text { Insoluble }\end{array}$ & $\begin{array}{c}-0.57 \\
\text { Very soluble }\end{array}$ & $\begin{array}{l}-7.16 \\
\text { Poorly soluble }\end{array}$ & $\begin{array}{c}-7.21 \\
\text { Poorly soluble }\end{array}$ & $\begin{array}{c}-7.83 \\
\text { Poorly soluble }\end{array}$ & $\begin{array}{l}-8.30 \\
\text { Poorly soluble }\end{array}$ & $\begin{array}{l}-7.32 \\
\text { Poorly soluble }\end{array}$ \\
\hline $\begin{array}{c}\text { LogS SILICOS- } \\
\text { IT } \\
\text { Class } \\
\end{array}$ & $\begin{array}{c}-5.39 \\
\text { Moderately } \\
\text { soluble }\end{array}$ & $\begin{array}{c}-17.50 \\
\text { Insoluble }\end{array}$ & $\begin{array}{c}0.15 \\
\text { Soluble }\end{array}$ & $\begin{array}{c}-4.59 \\
\text { Moderately } \\
\text { soluble }\end{array}$ & $\begin{array}{c}-4.91 \\
\text { Moderately } \\
\text { soluble }\end{array}$ & $\begin{array}{l}-6.09 \\
\text { Poorly soluble }\end{array}$ & $\begin{array}{l}-6.17 \\
\text { Poorly soluble }\end{array}$ & $\begin{array}{c}-5.30 \\
\text { Moderately } \\
\text { soluble }\end{array}$ \\
\hline
\end{tabular}

Table 3: The pharmacokinetic parameters of the identified compounds.

\begin{tabular}{|c|c|c|c|c|c|c|c|c|c|}
\hline \multirow[b]{2}{*}{ Compounds } & \multicolumn{9}{|c|}{ Properties } \\
\hline & $\mathrm{GIA}$ & BBB permeant & $\begin{array}{c}\text { P-gp } \\
\text { substrate }\end{array}$ & $\begin{array}{l}\text { CYP1A2 } \\
\text { inhibitor }\end{array}$ & $\begin{array}{l}\text { CYP2C19 } \\
\text { Inhibitor }\end{array}$ & $\begin{array}{l}\text { CYP2C9 } \\
\text { inhibitor }\end{array}$ & $\begin{array}{l}\text { CYP2D6 } \\
\text { inhibitor }\end{array}$ & $\begin{array}{l}\text { CYP3A4 } \\
\text { inhibitor }\end{array}$ & $\operatorname{LogKp}(\mathrm{cm} / \mathrm{s})$ \\
\hline 1 & High & No & No & Yes & No & Yes & No & No & -2.60 \\
\hline 2 & Low & No & Yes & No & No & No & No & No & 4.2 \\
\hline 3 & High & No & No & No & No & No & No & No & -7.44 \\
\hline 4 & High & Yes & No & Yes & No & Yes & No & No & 13.18 \\
\hline 5 & High & Yes & No & Yes & No & Yes & No & No & -3.07 \\
\hline 6 & High & No & No & Yes & No & No & No & No & -2.82 \\
\hline 7 & High & Yes & No & No & No & No & Yes & No & -3.96 \\
\hline 8 & Low & No & No & Yes & No & Yes & No & No & -2.66 \\
\hline
\end{tabular}


and 0.06 , respectively) whereas the other six demonstrated moderate activities, as potentials to modulate ion channels. Compound 1 is the most active compound against kinase enzyme with the bioactivity score of 0.00 , while other compounds had moderate activity with bioactivity scores in a range of -0.14 to -0.42 . These compounds, especially compound 1 have potential to treat infections caused by hyperactive protein kinases. Nuclear receptors are key regulators of various metabolic diseases such as diabetes. ${ }^{44}$ Based on our results, all compounds showed active (compound $1,3,5,6,7$ and 8 ) to moderate (compound 2 and 4 ) potential to inhibit nuclear receptors. This implies that these compounds are promising therapeutic alternatives to treat some metabolic disorders. Active protease inhibition was predicted for three compounds (compound 1,7 and 8) while the other compounds revealed moderate activity. The results reveal that the compounds can act as protease inhibitors.

\section{Toxicological predictions}

The toxicity assessment of compounds is an important step during drug discovery process. ${ }^{45}$ The toxicological predictions including mutagenicity, carcinogenicity and inhibition of hERG by the compounds are shown in Table 5. According to PreADMET, the negative prediction translates carcinogenic activity whereas positive means the compound does not have carcinogenic activity. About four compounds (compound 2, 6, 7 and 8) were found to be safe as they did not exhibit any mutagenic and carcinogenic effects. The compounds did also reveal to have low to medium probabilities of inhibiting hERG. The obstruction of the hERG gene is strongly associated with the prolonged QT syndrome, which often result in sudden heart attacks in humans. ${ }^{46}$ Based on these presumptions, all the compounds are safe for use as they show low to medium capabilities of blogging hERG gene.

\section{CONCLUSIONS}

It was observed that the majority of the compounds have good physicochemical profiles with several other ADMET properties. The drug-like property predictions showed that most of the compounds, except compound 2, comply to Ro5. Compound 2, 6, 7 and 8 are safe for use as they did not demonstrate any potential to be mutagenic and carcinogenic on the tested parameters. Moreover, all the compounds did show low to medium risks of inhibiting hERG. Furthermore, these predictive results should be validated by in vitro and in vivo toxicological

\section{ACKNOWLEDGMENTS}

The authors acknowledge the Research and Innovation Committee of the University of Zululand, for funding this research. The authors would like to also acknowledge the staff and postgraduate students in the Department of Biochemistry and Microbiology for their outstanding support.

Table 4: Drug-likeness and bioavailability properties of the compounds.

\begin{tabular}{cccc}
\hline \multirow{2}{*}{ Compounds } & \multicolumn{3}{c}{ Lipinski's rule } \\
\cline { 2 - 4 } & Satisfactory & Number of violations & Bioavailability \\
\hline 1 & Yes & 1 & 0.56 \\
2 & No & 2 & 0.17 \\
3 & Yes & 0 & 0.56 \\
4 & Yes & 0 & 0.56 \\
5 & Yes & 0 & 0.56 \\
6 & Yes & 1 & 0.55 \\
7 & Yes & 0 & 0.55 \\
8 & Yes & 1 & 0.55 \\
\hline
\end{tabular}

Table 5: Bioactivity score of the identified compounds.

\begin{tabular}{cccccc}
\hline \multirow{2}{*}{ Compounds } & GPCR ligand & $\begin{array}{c}\text { Ion channel } \\
\text { modulator }\end{array}$ & Kinase inhibitor & $\begin{array}{c}\text { Nuclear receptor } \\
\text { ligand }\end{array}$ & $\begin{array}{c}\text { Protease } \\
\text { inhibitor }\end{array}$ \\
\cline { 2 - 6 } & 0.17 & 0.07 & -0.22 & 0.23 & 0.07 \\
2 & -2.92 & -3.57 & -3.50 & -3.51 & -2.34 \\
3 & -1.59 & -0.96 & -2.25 & -1.60 & -1.53 \\
4 & -0.08 & -0.08 & -0.35 & -0.14 & -0.04 \\
5 & -0.04 & 0.05 & -0.42 & 0.01 & -0.11 \\
6 & 0.03 & -0.03 & -0.25 & 0.06 & -0.02 \\
7 & 0.21 & -0.01 & 0.00 & 0.12 & 0.14 \\
8 & 0.17 & 0.06 & -0.14 & 0.17 & 0.09 \\
\hline
\end{tabular}

Table 6: Toxicological properties of the identified phytocompounds.

\begin{tabular}{|c|c|c|c|c|}
\hline \multirow{3}{*}{ Compounds } & \multicolumn{4}{|c|}{ Toxicity } \\
\hline & \multirow{2}{*}{$\begin{array}{l}\text { Mutagenicity } \\
\text { (Ames test) }\end{array}$} & \multicolumn{2}{|c|}{ Carcinogenicity } & \multirow[b]{2}{*}{ hERG inhibition } \\
\hline & & Rat & Mouse & \\
\hline 1 & Mutagen & Positive & Positive & Low risk \\
\hline 2 & Non mutagen & Positive & Positive & Medium risk \\
\hline 3 & Mutagen & Negative & Negative & Low risk \\
\hline 4 & Mutagen & Positive & Positive & Low risk \\
\hline 5 & Mutagen & Positive & Negative & Low risk \\
\hline 6 & Non mutagen & Positive & Positive & Low risk \\
\hline 7 & Non mutagen & Negative & Negative & Low risk \\
\hline 8 & Non mutagen & Positive & Positive & Low risk \\
\hline
\end{tabular}




\section{CONFLICTS OF INTEREST}

The authors declare no conflict of interest.

\section{ABBREVIATIONS}

GC-MS: gas chromatography-mass spectrometry; GC: gas chromatography; MS: mass spectrometry; E. ferox: Encephalartos ferox; GPCR: G protein coupled receptor; MV: molecular weight, nHBA: number of hydrogen bond acceptors; nHBD: number of hydrogen bond donors; nRB: number of rotational bonds; ADME: absorption, distribution, metabolism and elimination; $\operatorname{cLog} P$ : octanol-water partition coefficient lipophilicity; LogS: solubility; GIA; gastrointestinal absorption; BBB: blood brain barrier; P-gp: p-glycoprotein; CYP: cytochrome P450 (CYP); LogKp: skin permeability; hERG: ether-a-gogo-related; Ro5: Lipinski rule of five.

\section{REFERENCES}

1. Humphreys G, Fleck F. United Nations meeting on antimicrobial resistance. World Health Organization. Bulletin of the World Health Organization. 2016;94:638

2. Balunas M.J, Kinghorn A.D. Drug discovery from medicinal plants. Life Sci. 2005;78:431-41.

3. Koomson D.A, Kwakye B.D, Darkwah W.K, Odum B, Asante M, Aidoo G. Phytochemical constituents, total saponins, alkaloids, flavonoids and vitamin $c$ contents of ethanol extracts of five solanum torvum fruits. Pharmacog J.2018;10

4. Organization WH. Traditional Medicine Strategy 2002-2005. 2002 (WHO/ EDM/TRM/2002.1). Online document at: http://www. who. int/medicines/ publications/traditional/policy/en/(accessed January 16, 2016).

5. De Graaf C, Vermeulen N.P, Feenstra K.A. Cytochrome P450 in silico: An integrative modeling approach. J Med Chem. 2005;48:2725-55.

6. Dearden JC. In silico prediction of drug toxicity. J Comput Aid Mol Des. 2003;17:119-27.

7. Lipinski CA. Lead-and drug-like compounds: the rule-of-five revolution. Drug Discov Today Technol. 2004;1:337-41.

8. Dong J, Wang NN, Yao ZJ, Zhang L, Cheng Y, Ouyang D, Lu AP, Cao DS. ADMETlab: a platform for systematic ADMET evaluation based on a comprehensively collected ADMET database. J cheminform. 2018;10:29.

9. Venugopala KN, Tratrat C, Chandrashekharappa S, Attimarad M, Sreeharsha N, Nair AB, Pottathil S, Venugopala R, Al-Attraqchi OHA, Morsy MA. Antitubercular potency and computationally-assessed drug-likeness and toxicology of diversely substituted indolizines. Indian J Pharm Educ. 2019;53:545-52.

10. Merlot C. Computational toxicology - a tool for early safety evaluation. Drug Discov Today. 2010;15:16-22.

11. Hossain MU, Khan M, Rakib-Uz-Zaman SM, Ali MT, Islam M, Keya CA, Salimullah M. Treating diabetes mellitus: Pharmacophore based designing of potential drugs from Gymnema sylvestre against insulin receptor protein. Biomed Res Int. 2016:2016.

12. Ojo MC, Osunsanmi FO, Zaharare GE, Mosa RA, Cele ND, Oboh MO, Opoku AR. In-vitro anti-diabetic and antioxidant efficacy of methanolic extract of Encephalartos ferox leaves. Pharmacog J. 2019;11.

13. Cousins SR, William SVL, Witkowski ETF. Sifting through cycads: A guide to identifying the stem fragments of six South African medicinal Encephalartos species. IS Afr J Bot. 2013;84:115-23.

14. Hussein $\mathrm{HM}$, Hameed IH, Ibraheemr OA. Antimicrobial activity and spectral chemical analysis of methanolic leaves extract of Adiantum capillus-veneris using GC-MS and FTIR spectroscopy. Int J Pharmacogn Phytochem. Res. 2016;8:369-85

15. Semwal P, Painuli S, Badoni H, Bacheti RK. Screening of phytoconstituents and antibacterial activity of leaves and bark of Quercus leucotrichophora A. Camus from Uttarakh and Himalaya. Clin Phytoscience. 2018;4:30.

16. Al-Marzoqi AH, Hadi MY, Hameed IH. Determination of metabolites products by Cassia angustifolia and evaluate antimicobial activity. J. Pharmacognosy Phytother. 2016;8:25-48.

17. Swamy MK, Sinniah UR, Akhtar M.S. In vitro pharmacological activities and GCMS analysis of different solvent extracts of Lantana camara leaves collected from Tropical Region of Malaysia. Evid Based Complementary Altern Med. 2015;2015.

18. Rahman MM, Ahmad SH, Mohamed MTM, AbRahman MZ. Antimicrobial compounds from leaf extracts of Jatropha curcas, Psidium guajava, and Andrographis paniculata. Sci World J. 2014;2014.
19. Padmashree MS, Roopa B, Ashwathanarayana R, Raja N. Antibacterial properties of Ipomoea staphylina Roem \& Schult. Plant extracts with comparing its preliminary qualitative phytochemical and quantitative GC-MS analysis. Trop Plant Res. 2018;5:349-69.

20. Kandhasamy M, Chinnasamy PS, Parimala S. Phytochemical evaluation of seed and fruit pulp extracts of Passiflora foetida L. World J Pharm Res. 2018;7:192432.

21. Ilieva $Y$, Kokanova-Nedialkova Z, Nedialkov P, Momekov G. In silico ADME and drug-likeness evaluation of a series of cytotoxic polyprenylated acylphloroglucinols, isolated from Hypericum annulatum Morris subsp. annulatum. Bulg Chem Commun. 2018;193

22. Daina, A.; Michielin, O.; Zoete, V. SwissADME: a free web tool to evaluate pharmacokinetics, drug-likeness and medicinal chemistry friendliness of small molecules. Sci Rep. 2017;7:42717.

23. Lipinski CA, Lombardo F, Dominy BW, Feeney PJ. Experimental and computational approaches to estimate solubility and permeability in drug discovery and development settings. Adv Drug Delv Rev. 1997;23:3-25.

24. Verma A. Lead finding from Phyllanthus debelis with hepatoprotective potentials. Asian Pac J Trop Biomed. 2012;2:S1735-7.

25. Cunha EL, Santos CF, Braga FS, Costa JS, Silva RC, Favacho HA, HageMelim LI, Carvalho JC, da Silva $\mathrm{CH}$, Santos CB. Computational investigation of antifungal compounds using molecular modeling and prediction of ADME/ Tox properties. Journal of Computational and Theoretical Nanoscience. 2015;12:3682-91.

26. Handa SS. Medicinal plants-priorities in Indian medicines diverse studies and implications. Supplement to Cultivation and Utilization of Medicinal Plants. 1996:33-51.

27. Srimai V, Ramesh M, Parameshwar KS, Parthasarathy T. Computer-aided design of selective cytochrome P450 inhibitors and docking studies of alky resorcinol derivatives. Med Chem Res. 2013;22:5314-23.

28. Veber DF, Johnson SR, Cheng HY, Smith BR, Ward KW, Kopple KD. Molecular properties that influence the oral bioavailability of drug candidates. J Med Chem. 2002;45:2615-23.

29. Muegge I, Heald SL, Brittelli D. Simple selection criteria for drug-like chemical matter. J Med Chem. 2001;44:1841-6.

30. Arnott JA, Planey SL. The influence of lipophilicity in drug discovery and design Expert Opin Drug Discov. 2012;7:863-75.

31. Kerns EH, Di L. Pharmaceutical profiling in drug discovery. Drug Discov Today 2003;8:316-23

32. Stegemann S, Leveiller F, Franchi $D$, De Jong $H$, Lindén $H$. When poor solubility becomes an issue: from early stage to proof of concept. Eur J Pharm Sci. 2007;31:249-61.

33. Daisy P, Suveena S, Rajalakshmi M, Lilly V. Ligand based virtual screening on natural compounds for discovering active ligands. Der Pharm Chem. 2011;3:51-7

34. Wang $Y$, Xing J, Xu Y, Zhou N, Peng J, Xiong Z, Liu X, Luo X, Luo C, Chen K, Zheng $\mathrm{M}$. In silico ADME/T modelling for rational drug design. Q Rev Biophys. 2015;48:488-515.

35. Borra NK, Kuna Y. Evolution of toxic properties of antialzheimer's drugs through Lipinski's rule of five. Int J Pure App Biosci. 2013;1:28-36.

36. Levin GM. P-glycoprotein: why this drug transporter may be clinically important. Curr Psychiatry. 2012;11:38-40

37. Khan MF, Bari MA, Islam MK, Islam MS, Kayser MS, Nahar N, Al-Faruk M, Rashid MA. The natural anti-tubercular agents: In silico study of physicochemical, pharmacokinetic and toxicological properties. J App Pharm Sci. 2017;7:034-8.

38. Lynch T, Price A.L. The effect of cytochrome P450 metabolism on drug response, interactions, and adverse effects. Am Fam Physician. 2007;76:391-6.

39. Chow HS, Garland LL, Hsu CH, Vining DR, Chew WM, Miller JA, Perloff M, Crowell JA, Alberts DS. 2010. Resveratrol modulates drug-and carcinogenmetabolizing enzymes in a healthy volunteer study. Cancer Prev Res. 2010;3:1168-75

40. Ng KW, Lau WM. Skin deep: the basics of human skin structure and drug penetration. Percutaneous penetration enhancers chemical methods in penetration enhancement. 2015:3-11.

41. Paramashivam SK, Elayaperumal K, Natarajan B, devi Ramamoorthy $M$, Balasubramanian S, Dhiraviam KN. In silico pharmacokinetic and molecular docking studies of small molecules derived from Indigofera aspalathoides Vah targeting receptor tyrosine kinases. Bioinformation. 2015;11:73.

42. El-Kattan A, Varma M. Oral absorption, intestinal metabolism and human ora bioavailability. Topics on Drug Metabolism. 2012;10:31087.

43. Singh S, Gupta AK, Verma A. Molecular properties and bioactivity score of the Aloe vera antioxidant compounds-in order to lead finding. Res J Pharm Biol Chem Sci. 2013;4:876-81.

44. Yang C, Li Q, Li Y. Targeting nuclear receptors with marine natural products. Marine Drugs. 2014;12:601-35. 
45. Mishra SS, Sharma CS, Singh HP, Pandiya H, Kumar N. In silico ADME, Bioactivity and Toxicity Parameters Calculation of Some Selected AntiTubercular Drugs. Int J Pharm Phytopharm Res. 2016;6:77-9.
46. Yu HB, Zou BY, Wang XL, Li M. Investigation of miscellaneous hERG inhibition in large diverse compound collection using automated patch-clamp assay. Acta Pharmacol Sin. 2016;37:111-23.

\section{GRAPHICAL ABSTRACT}

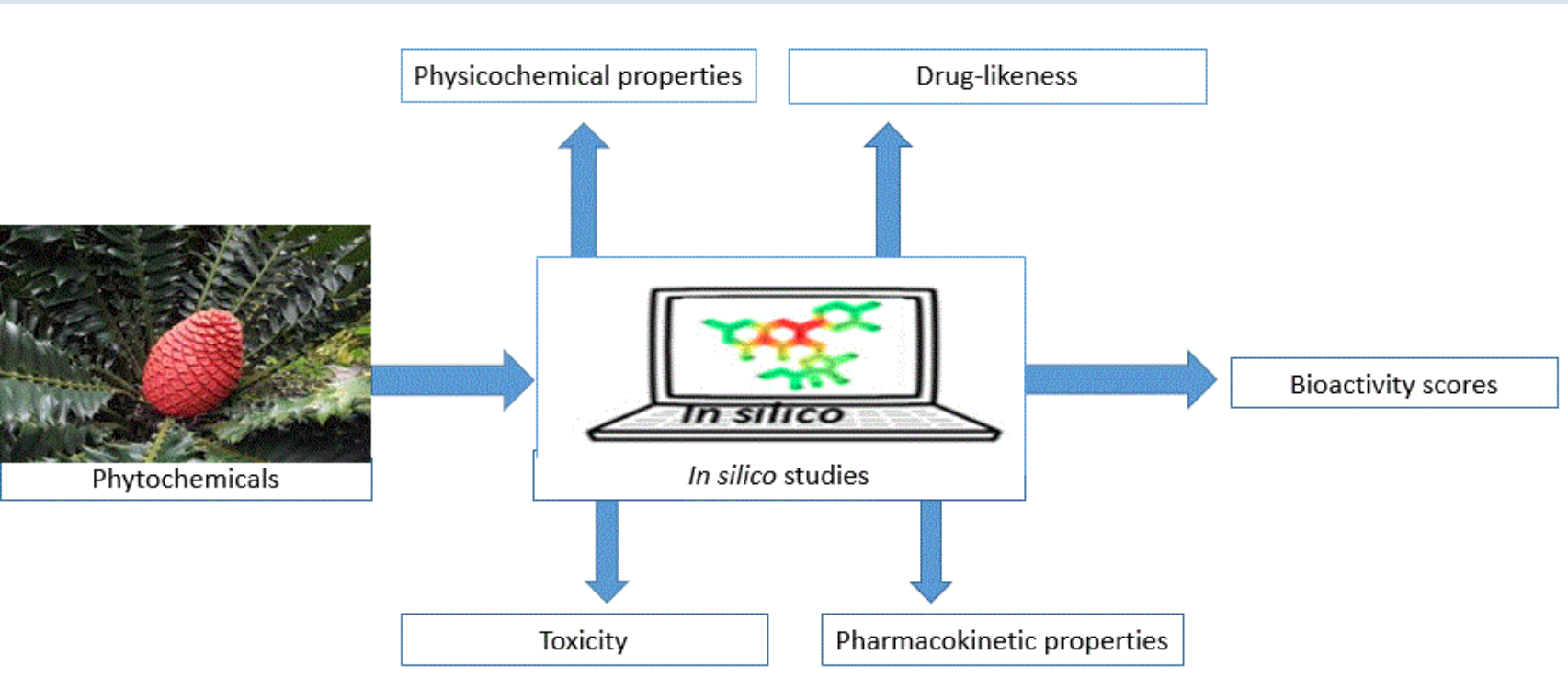

\section{ABOUT AUTHORS}
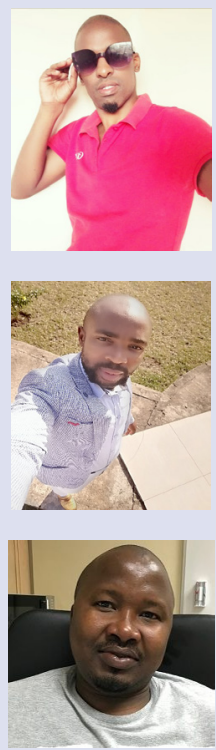

\section{Mr. Jabulani Siyabonga Shandu}

Position: Lecturer

Phone: (035)902-6201

Email: Shanduj@unizulu.ac.za

Building \&Room: Room, Sc.255, 1ST Floor, Natural Science Building Biography:

Mr J.S. Shandu is a lecturer in the field of Microbiology at the University of Zululand at kwa-Dlangezwa campus. He holds an MSc. degree in Microbiology. His research interests are in phytomedicine and aquatic microbiology.

Qualifications:

BSc, BSc (Hons.), MSc. (Microbiology). University of Zululand.

Research interests:

Medicinal plant properties and Water quality monitoring

Professional membership:

- SASM-KZN

Research Databases / Publications:

Has published on several academic journals since 2008, particularly in phytomedicine.

Cite this article: Maliehe TS, Tsilo PH, Shandu JS. Computational Evaluation of ADMET Properties and Bioactive Score of Compounds from Encephalartos ferox. Pharmacogn J. 2020;12(6):1357-62. 